\title{
CORREÇÃO DE MORDIDA ABERTA ANTERIOR COM USO DE ESPORÕES LINGUAIS - RELATO DE CASO CLÍNICO
}

Renata dos Santos VIANNA, Miguel Angelo da CUNHA NETO, Rodrigo Anderson do ESPÍRITO SANTO

A mordida aberta anterior é uma das maloclusões de correção mais difícil, e sua etiologia geralmente está associada ao impedimento mecânico para a total erupção dos dentes anteriores, seja pelo hábito contínuo de sucção de dedos ou chupetas, seja por uma postura inadequada da língua, que ocupa o espaço interdental tanto durante o ato de deglutição ou fonação, como em sua posição postural de descanso. Existem inúmeras alternativas de tratamento para esta patologia através de aparelhos impedidores, como por exemplo, as grades ou os esporões. O objetivo deste trabalho foi avaliar a eficácia dos esporões linguais, através de relato de caso clínico. Paciente do sexo feminino, 8 anos e 2 meses de idade, na fase de dentição mista, com padrão esquelético classe I, mordida aberta anterior, incisivos vestibularizados e hábito postural inadequado da língua. A paciente utilizou o aparelho durante 2 anos e meio, sendo submetida a uma avaliação clínica a cada 3 meses. O que pôde ser observado foi uma correção da mordida aberta anterior, além de uma melhora na inclinação dos incisivos, comprovando a eficácia deste aparelho que vem sendo pouco utilizado durante os últimos anos por ser erroneamente considerado traumático. 